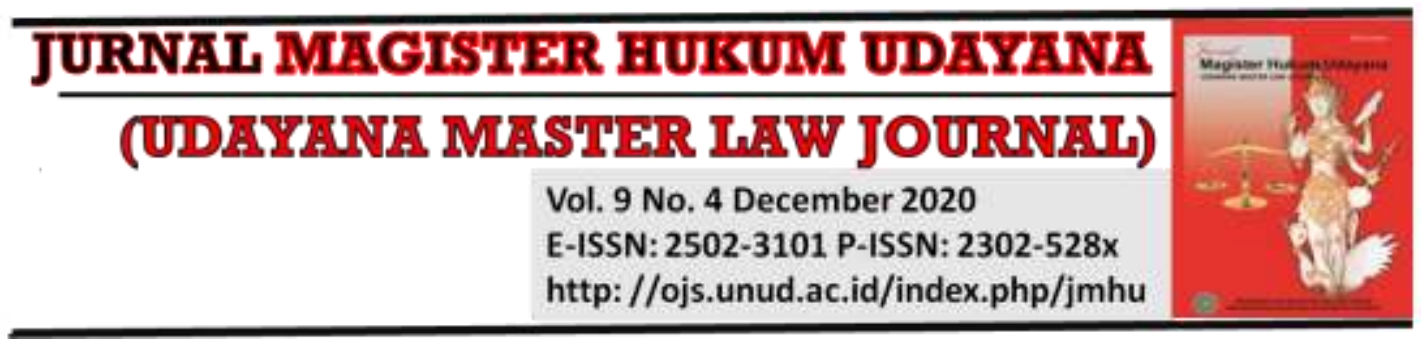

\title{
The Concept of Special Judicial Institutions in Dispute Resolution of Village Heads In Indonesia
}

\author{
Fauziyah $^{1}$, I Wayan Parsa ${ }^{2}$ \\ ${ }^{1}$ Faculty of Law Muhammadiyah University Jember, Post Doctoral Faculty of Law Airlangga \\ University, E-mail: fauziyah@unmuhjember.ac.id \\ ${ }^{2}$ Faculty of Law Udayana University, E-mail : wayanparsa20@gmail.com

\begin{tabular}{l}
\hline Info Artikel \\
\hline Masuk: $29^{\text {th }}$ April 2020 \\
Diterima: $29^{\text {th }}$ December 2020 \\
Terbit: $31^{\text {st }}$ December 2020 \\
Keywords: \\
Special yudicial institution; \\
election Of Village Heads; \\
dispute \\
Kata kunci: \\
Lembaga yudisial khusus; \\
Pemilihan Kepala Desa; \\
perselisihan \\
Corresponding Author: \\
Fauziyah, Email : \\
fauziyah@unmuhjember.ac.id \\
\\
DOI: \\
10.24843/JMHU.2020.v09.i04. \\
p01
\end{tabular}

\begin{abstract}
The idea of village head dispute resolution through the Special Judicial Institution began with anxiety over Law 6 of 2014 concerning Villages, Government Regulation number 6 of 2014 concerning Implementation of Village Laws, and Minister of Home Affairs Regulation No. 112 of 2014 concerning Guidelines for Election of Village Heads, which has not yet regulated the village head election supervisory institutions and dispute resolution institutions for village head elections. The institutions that are required to complete based on these rules are Regents with a period of 30 days. Regents are political positions which also have many political interests. The existence of this decision had an impact on one of the candidates for the village head. The current practices for resolving disputes over village head elections through the District Court and the State Administrative Court. The purpose of this study to create a concept for regional special judiciary institutions in resolving regional election disputes in Indonesia. This research using a normative juridical approach with a statute approach, history approach and conceptual approach. The results of the study show that by establishing a special independent judicial institution based on local wisdom by prioritizing the principle of kinship and consensus building. The main task of the institution is to assist the regional head in providing alternative legal services, to serve and protect the rights of the parties in seeking truth and justice, and to settle according to a predetermined time, to try to examine and decide on cases of village head election disputes.
\end{abstract}

\section{Introduction}

Indonesia as a legal state (rechtstaat) according to the constitution of Article 1 Paragraph (3) of 1945 Constitution. In the state of law, the law of sich is a guidance for any actions or actions carried out or not carried out within the territory of said legal state. ${ }^{1}$ Friedrich Julius Stahl declaring a rule of law must at least have several characteristics, namely there is protection of Human Rights (HAM), there is

\footnotetext{
${ }^{1}$ Ahmad, H., Anshari, T., \& Widagdo, S. (2018). Politik Hukum Pengaturan Penyelesaian Perselisihan Hasil Pemilihan Kepala Desa. Mahkamah: Jurnal Kajian Hukum Islam, 3(1), 129140. h. 130.
} 
separation or division of power (separation of power or distribution of power), and the existence of government based on regulations (wetmatigheid van bestuur), and the existence of an administrative court that is free in disputes. The oldest democracy in Indonesia is believed by most to be village democracy, because it was earlier grown and unique. ${ }^{2}$ This democracygrows and takes root as a form of democracy today. Opinion of Mohammad Hatta original democracy is located in the village and the government entity is directly related to the people. The characteristics of village democracy are, among others, 1). meeting (where people deliberate to reach consensus). 2.) people's rights to protest and 3.) a culture of help - help. The concept of Concurrent Village Head Election (Pilkades) is directly older than in the direct post- conflict local election or presidential election even village democracy has existed since the kingdom of Indonesia. ${ }^{3}$

Village democracy grows and develops according to the conditions and characteristics of communal values in the village. The state did not interfere in the first place and regulate the affairs of village head elections, the tenure of the village head, the duties and responsibilities of the village government, as well as regarding the appointment and dismissal of the village head. ${ }^{4}$ Including the dispute over village head elections, everything was left to the village itself to solve it in accordance with local competitiveness and the mechanisms in each village. ${ }^{5}$

${ }^{2}$ Rudiadi, R., \& Herawati, R. (2017). PEMILIHAN KEPALA DESA SERENTAK DALAM PERSPEKTIF OTONOMI DESA (Studi Kasus Pelaksanaan Pemilihan Kepala Desa Serentak Tahun 2016 di Kabupaten Rokan Hilir, Provinsi Riau). LAW REFORM, 13(1), 132-151. DOI: https://doi.org/10.14710/lr.v13i1.15956 h. 133

${ }^{3}$ Hanif Nur Cholis, the origin of Village in Indonesia, MIPI Journal, Edition 382013 describes the ranking of villages being older than larger kingdoms. Before the presence of a larger kingdom, the village level was truly independent, the independence of the village began to be disturbed after the establishment of a stronger and bigger kingdom. Evidence that the village submits to the kingdom's authority, he offers tribute and performs worship to the king once a year on predetermined months and days. https://young historian.wordspress.com/2019/07/01 democracy-native-Indonesia-and sovereignty-peoplemohammad hatta / accessed on Sunday, March 162019.

${ }^{4}$ The era of the Dutch East Indies Government, the village government was regulated in Article 118 Jo. Article 121 I.S is in the form of the Dutch East Indies constitution. This rule interprets the indigenous people to be left under the direct control of their own heads (leadership). Then further rules were outlined in IGOB (Inlandsche Gementee Ordonantie Buitgewenstent) LN 1938 no. 490 valid since January 1939 LN 1938 No 681. The name and type of the indigenous community is the Bumi Putera community. The alliance of indigenous Javanese people is called Desa, in the former residency of Palembang it is called Marga, Nagari in Minangkabau while in the former residency of Bangka Belitung it is called Haminte. Ibid, p. 4

${ }^{5}$ History of democratic dynamics in Indonesia; democracy in the revolutionary era from 19451950 was proven by the government's policy in the form of government decree No. X 16 October 1945, KNIP as legislative, Government Declaration No. November 3, 1945 The formation of political parties, as well as the government's announcement on November 14, 1945, changed the composition of the cabinet, the era of liberal democracy (1990-1959), which is also called the era of parliamentary democracy with arguments after the implementation of the parliamentary system under the auspices of the 1945 First Period of Constitution, the RIS constitution, and Provisional constitution 1950. Democracy in the New Order era in 1966-1998, began with the determination of Pancasila and the original and consistent 1945 Constitution. Democracy in reform era 1999 - present. Increasing the principles of democracy is manifested 
New state intervention began to be dominant when in 1979 during the new order, the government regulated the procedures for selecting village heads and village officials including limiting the term of office of village heads through Law No. 51979 concerning the Village Government. ${ }^{6}$ However, Law No. 5 of 1979 did not at all regulate the model of dispute resolution of village head elections. ${ }^{7}$ The procedure for village head elections continues to experience various developments and changes. During the Dutch colonial era, the election of direct village heads in a number of regions was carried out by the respective voters and supporters of the village head making long marches on the ground, giving rise to Core supporters whose names were GAPIT or known as the village head's success team. The elected village head candidate has the longest line of voters or supporters.

The method of choosing a village head is open, so that it has the potential to cause horizontal conflicts between supporters of each other, because they know each other who is the village head they choose. Then the village head election is carried out by closed direct election. Direct village head elections continue to experience developments and changes, especially related to technical voting. If previously using sticks or weeds inserted in a bamboo barn, now use a sound card containing photos and names and the voters use their voting rights by voting for images or photos of their chosen candidates. The results of vote counting are calculated based on the most votes as winners.

The principle with the change in method is to produce the best village head and realize village democracy, independence and welfare of the village community. ${ }^{8}$ The state delegates the matter of dispute resolution to the selection of regional head of village through the regent, even though the regent is a political official who is closely related to the appointment and appointment of elected village heads. ${ }^{9}$ From the description above, the researcher was interested in conducting research under the title "The Concept of Special Judicial Institutions in Dispute Resolution of Village Heads in Indonesia".

through the enforcement of Human Rights Law no. 39 of 1999 on Human Rights. the 1945 constitution four times in 1999, 2000, 2001, and 2002 aimed at improving democracy in accordance with the principles of a democratic state.

${ }^{6}$ The era of the new order, regulations related to villages are regulated through Law No. 5 of 1979, aims to perceive the name, form, composition and position of village government. This law regulates the village in terms of governance, in contrast to the Marga government, in addition to regulating the customs of the New Order regime, customary villages experience tremendous pressure from the state through the uniform system of village government within a centralistic administrative unit through Law No. 5 of 1979 concerning the Village. New Order era The village has become an extension of the central government acting uniformly in a centralized command. The adat village was then destroyed as a unit of government, social, economy and culture of the customary law community.

${ }^{7} \mathrm{Ni}^{\prime}$ matul Huda, Village Governance Law Since Independence Until the Reform Era, Setara Press Malang, 2020, p. 36. Check also Elections of village heads from the Dutch period to the reform period written by a Carton master. Posted by Master kardon Thursday, may 302013. http: // katon media. blogspot.com/2013/05/ village head election from the era. Accessed 12 Maret 2019.

${ }^{8}$ Syahrul Mustofa, Mahkamah Penyelesaian Sengketa Pemilihan Kepala Desa Serentak, Guepedia, h. 8

${ }^{9}$ Ibid, h. 19 


\section{Research Method}

Methods in Research using the type of normative juridical research (normative legal research). With an approach to legislation (statute approach), conceptual approach and historical approach. ${ }^{10}$

\section{Result and Discussion}

\subsection{Supervision of simultaneously Village Head Election as a Form of Direct, General, Free, Secret, Honest and Fair Democracy}

The key to the successful implementation of village head elections is direct, general, free, confidential, honest and fair by conducting intense and effective supervision by independent and impartial institutions which are tasked with overseeing all stages of village head elections and resolving disputes at the village head election stage ${ }^{11}$ So the presence of a village head election supervisory institution must be established by the local government on the grounds:

First, village head elections without supervision only give birth to a ritual of succession alone, actualization and manifestation of popular sovereignty is difficult to realize because village head elections will run without the principles of free and fair election, fraudulent practices have the opportunity to occur throughout where and take place freely. The potential for fraud or violations of village head elections are massive, structured, and systematic, very wide open. On the other hand, the public will be increasingly powerless to deal with various fraudulent practices that exist, and tend to allow them to because the community does not know how to complain about fraud. In the absence of channel aspirations, what people want will be clogged, and will encourage people to look for other effective aspiration channels.

Second, unattended village head elections will give birth to various problems and increase the number of violations. Due to the clogging of channels of community aspirations so that the accumulation will trigger the birth of conflict, because there are no problems and cheating of village head elections without supervision, candidates for village heads, village head election committees and voters do not understand their rights and obligations, do not know which are allowed and prohibited. Or in other words, blind to the purpose of democracy, because they do not know the direction and purpose of the election of the village head itself. In addition, there can also be a truth claim for each party, because the measure of truth used is subjective. In addition, it could give rise to more and more disputes over village head elections which ended in court.

Third, the election of village heads without supervision will give rise to the rise of money politics. Money politics happens everywhere and anytime. Everyone can do it

\footnotetext{
${ }^{10}$ Peter Mahmud Marzuki. (2012). Penelitian Hukum. Jakarta. Kencana Prenada Media Group. h.133.

${ }^{11}$ Mashuri Mashab. (2013). Politik Pemerintahan Desa di Indonesia, Cetakan 1. Yogyakarta. Fisip UGM. h. 3
} 
so that money politics becomes commonplace, despicable or embarrassing actions or violations that threaten democracy. Furthermore, the practice of money politics is no longer done in a hidden way, thus threatening to undermine true democracy. The voice of the people as owners of sovereignty will be pawned very easily and cheaply. Besides that, it can give birth to "jungle law", who is strong he is the one in power. Candidates for village heads who are strong with money, will do politic money, while candidates who are strong because of their physicality will intimidate to be in power, and those who like to cheat will cheat their voters in various ways they have.

Fourth, the election of village heads without supervision will give birth to village heads who have "false legitimacy" because they are elected not because of their capacity, capability and integrity and carry out all rules of the game, implementing the principle of direct, free, confidential, honest and fair village head elections. But because of the greatness of doing everything in achieving power, including the way that is unclean (money politics) though. Election of village heads with low integrity results in violations of certain norms. So that a positive aspect is needed in the integrity of the Pilkades election and it needs to be upheld so that democracy is not only a dream. ${ }^{12}$ In addition, it can cover up the elimination of the ideals of democracy, because an impossibility of direct, general, confidential, honest and fair, dignified and integrity village head elections will be realized if violations and fraud have occurred early, starting from the total voter collection stage.

The implementation of the general direct election principle, free of secrecy, honesty and fairness is difficult to realize when the process of implementing village head elections is colored by various fraudulent practices. To anticipate this, it is necessary to establish a village head election supervisory committee. In law number 6 of 2014, Government Regulation No. 43 of 2014 and Minister of Home Affairs Regulation No. 112 of 2015 concerning the Election of Village Heads, are not mentioned at all regarding the institution of supervision of village head elections simultaneously. Because the election of village heads is regulated in the Regional Regulations of each Regency, there needs to be an initiative from the local government to establish a supervisory committee where these institutions must have positions, duties and roles not only oversee the process of implementing village head elections, but rather become supervision and control institutions. the election of the head of village and directs the village head election committee to truly implement the provisions of the legislation, as well as a forum for the community to complain of violations and resolve the problems in the stages of village head elections.

The function and role of the supervisory institution can be carried out properly so that it can be placed at the district level. Because the duty of the subdistrict head is as an extension of the regional government (regent), the subdistrict head has the duty and authority to provide guidance to the village. One of the sub-district leaders is in the village administration. ${ }^{13}$

\footnotetext{
${ }^{12}$ Mutiarasari, N. N., \& Herawati, R. Supervision of Bawaslu Pemalang Regency in the 2020 Regional Head Election. LAW REFORM, 16(2), 264-275. DOI: https://doi.org/10.14710/lr.v16i2.33777

${ }^{13} \mathrm{Ni}$ 'matul Huda Op. Cit h.178.
} 


\subsection{Special Judicial Concept in Resolving Disputes Over Simultaneously Village Chief Election}

The Special Judicial Concept in resolving Disputes over Simultaneous Village Chief Election. ${ }^{14}$ Even the International Institute for Democracy and Electoral Assistance (IDEA) states that there is room for submitting electoral complaints and enforcement of electoral law (compliance and enforcement of electoral law) as a standard for democratic elections. ${ }^{15}$ The public can control the implementation of the election whether it is in accordance with the laws and regulations or not. The Election Association for Democracy (Perludem) formulates 10 guidelines for good elections as follows: ${ }^{16}$
a) Effective mechanism and legal settlement;
b) There are rules regarding penalties for violations of elections;
c) There are detailed and adequate provisions to protect voting rights;
d) There is a right for voters, candidates to complain to electoral institutions or court institutions;
e) The right to appeal;
f) The existence of a decision as soon as possible;
g) There are rules regarding the time needed to decide a lawsuit;
h) There is clarity regarding the implications for violating Election rules on the results of the General Election;
i) There are processes, procedures and prosecutions that respect human rights.

The history of resolving disputes over the results of village head elections in Indonesia, there are no laws specifically regulating the law specifically regulating the institutions and mechanisms for resolving dispute over village head election results.

Before the enactment of the Village Law Number 6 of 2014 concerning villages, Government Regulation number 6 of 2014 concerning the implementation of law number 6 of 2014 concerning villages and the 2014 Minister of Internal Affairs regulation on general guidelines for the implementation and dispute resolution of elections led to the law number 32 of 2004 concerning the regional government and its implementing regulations, namely government regulation number 72 of 2005 concerning villages.

However, the two rules above do not regulate in detail about the election conflict resolution, only mandating the regions to regulate the settlement of elections to the village regulated by regional regulations. In PP 72 of 2005 Article 53 is stated as follows:

(1) Further provisions concerning procedures for the selection, nomination, appointment of inauguration, and dismissal of village heads are regulated by Regency / City regulations.

\footnotetext{
${ }^{14}$ International Institute for Democracy and Electoral Assistance. (2010). Keadilan Pemilu, Ringkasan Buku Acuan International IDEA. Jakarta. Indonesia Printer. h. 5

15 Ramlan Surbakti, dkk. (2011). Penanganan Sengketa Pemilu. Jakarta. Kemitraan Bagi Pembaharuan Tata Pemerintahan. h. 2

${ }^{16}$ Titi Angraini dkk. (2011). Menata Kembali Pengaturan Pemilukada. Jakarta. Perludem. h. 73-74
} 
(2) Regency/city Regional Regulations as referred to in paragraph (1), at least contain as kinds of things, one of which is the mechanism of complaints and problem solving.

In order to carry out the mandate of government regulation number 72 of 2005 concerning the village, the local government of West Sumbawa regency, then form regional regulation number 25 of 2006 concerning the election, ratification and dismissal of village heads in conjunction with regional regulation number 20 of 2008 concerning changes to the West Sumbawa district regulations number 25 in 2006 concerning, ratification and dismissal of the village head.

In Government Regulation number 72 of 2005 concerning villages, the term used is a problem not a dispute, so it is related to all problems in the implementation of village head election. It does not limit what problems in the election of the village head and what must be resolved by the region, the scope and objects are so wide. It is also not regulated in the Government Regulation whether the problem is resolved by the local government or by the judicial institution.

Therefore, in PP number 72 of 2005 concerning villages it does not clearly regulate whether the resolution of the problem or dispute over village head election is the territory of the judiciary, does not regulate the object of the dispute, the deadline for completion and the settlement procedure. Subsequently, the regional government tried to take the initiative to limit the object of disputes, institutions that handle disputes and the deadline for resolving disputes stipulated in the previous regional regulation, namely local regulation number 25 of 2006 concerning the election, ratification and dismissal of village heads in conjunction with regional regulation number 20 of 2008 concerning changes to West Sumbawa district regulation number 25 of 2006 concerning the election of ratification and dismissal of village heads. Village head dispute resolution stipulated in Article 70 says "in the event that an objection to the determination of election results can only be submitted by the candidate whose vote is significant (influential) on the results of the village head election to the District Court no later than 3 (three) days after the determination of results election. Furthermore, it was said that the objection was only pleasing to the results of the vote counting which influenced the election of candidates. The District Court decides the dispute over the results of the vote count as referred to in paragraph (1) and paragraph (2) no later than 14 (fourteen) days from the receipt of the objection request by the candidate.

District court decisions are final and binding. After the decision of the district court, the local election committee submits the determination of the elected candidate and the decision no later than 3 (three) days after the verdict is dropped. Thus, the pilkades dispute resolution in the regional regulation previously tried to limit the object of disputes over village head elections, which only included the matter of calculating and determining the results of vote acquisition, and the institution to settle it was a district court, with a time limit of 14 (fourteen) days.

The basis for the formulation of the material for the regional regulation is to adopt a model or dispute resolution system that exists in regional head elections used by the constitutional court of the Republic of Indonesia in resolving electoral disputes over the region. However, the provisions of Article in the Regional Regulation are difficult 
to be carried out by the Sumbawa District Court, especially related to the regional regulation limit for only 14 (fourteen) days. The obstacles faced by the District Court in implementing the regulation are (1) the Sumbawa District Court does not have special judges who manage the election dispute resolution, and (2) village head election dispute resolution refers to the ordinary procedural law used in the trial process, so in fact the assembly decision can only be decided 3 (three) months later after the case register list is submitted. ${ }^{17}$

Likewise the provisions of the Decision which are final and binding cannot be implemented by the Sumbawa District Court because the Sumbawa District Court is bound by the existing judicial system and applicable procedural law within the Sumbawa district court, where the applicant / plaintiff in accordance with applicable procedural law can file an appeal to the high court or appeal to the Supreme Court of the Republic of Indonesia, when feeling dissatisfied with the verdict handed down by the district court judges. Or in other words, previous Regional Regulations cannot regulate the judiciary. Because local regulations cannot regulate the jurisdiction of the jurisdiction of the judiciary.

The regional head is a political position. ${ }^{18}$ Which is considered not value- free by the candidate of the village head, so that the decision of the regional head is always sued by the village head candidate because it is judged that the decision of the regional head is considered not neutral, or siding with certain candidates. That is why, every village head election is crowded - many regional heads are sued and the regional heads are made "dizzy" by election.

\subsection{Legal formal for the Establishment of Special Courts to settle disputes over village head elections simultaneously.}

Juridically, the establishment of special courts at the regional level is based on the following laws and regulations:

1. Article 18 paragraph (6) of the 1945 Constitution;

2. Law Number 6 of 2014 concerning Villages;

3. Law Number 23 Year 2014 concerning Regional Government;

4. 4.Government Regulation Number 43 of 2014 concerning Regulations on the implementation of Law 6 of 2014;

5. Minister of Home Affairs Regulation Number 1 of 2014 concerning Establishment of Regional Legal Products;

6. Minister of Home Affairs Regulation Number 112 of 2014 concerning Election of Village Heads.

The legal formal above is a form of the formation of a special adhoc body that has the main task of deciding, examining and adjudicating disputes over the results of village head elections. This institution was formed and proposed by the village head election committee at the district level with the approval of the Regional Head. The aim of this

\footnotetext{
${ }^{17}$ Syahrul Mustofa, Op. Cit

${ }^{18}$ The meaning of a political position, is a position generated by a political process, for example, Governor, Deputy Governor. President, Vice President, and their ministers who are included in political positions: Law No. 43/1999: Amendments to Law No. 08 of 1974 concerning Personnel Principles Article 11, political positions are categorized as state officials, among others, are the heads of the regents/cities and deputy regents/deputy mayors.
} 
institution is to help resolve village head election disputes. Domiciled in the area (capital city) with an odd number of assemblies of at least 3 (three) people and who apprehended many 9 (nine) people, led by 1 (one) chairperson, 2 (two) deputy chairmen and the remaining members elected by members of the Court of Justice Especially the election of village heads with the approval of the Regional head based on the Regent's Decree.

The elements of the assembly in a special court institution come from elements of regional government representation and elements of the community who fulfill the requirements as a special court including having knowledge of local regulations, knowledge of village head elections, having experience in resolving legal cases, having capability, professionalism, and good integrity, willing to carry out independent and impartial principles in prosecuting and deciding cases, as well as being full-time to resolve disputes over village head elections.

The principles used in deciding in the Special Court of dispute over village head elections are among others: ${ }^{19}$

1. The decision principle is final;

2. Principle of presumption rechtmatig;

3. The principle of free proof;

4. Principle of activeness of judges to investigation;

5 . The ruling principle has binding legal force;

6. Independent principles;

7. The principle of active and passive judges in the trial process;

8. The principle of justice is simple, fast, and low-cost;

9. Principle The session is open to the public and is limited;

10. Principle of objectivity;

11. Erga Omnes principle is limited;

12. The principle of audi et alteram Partem (heard equally);

13. Principle ius Curia Novit.

\section{Conclusion}

The concept of a special court institution in resolving disputes over village head elections is adhoc where the institution is formed based on proposals from the village head election committee with the approval of the Regional Head based on the Regent Decree, which aims to; a.) safeguarding and guarding village democracy, b.) protecting the rights of parties in seeking truth and justice for the results of village head elections by treating equal positions for all parties, c.) resolving disputes over peaceful village election elections based on values local wisdom in the area. d.) assist regional heads in order to resolve disputes over election results towards the village independently, professionally, transparently, accountably, based on applicable regulations. The decision of this special court institution is final and has permanent legal force.

\footnotetext{
${ }^{19}$ Muryati,Dewi Tuti, B. Rini Heryanti . (2011). Pengaturan dan Mekanisme Penyelesaian Sengketa Non Litigasi di Bidang Perdagangan. Jurnal Dinamika Sosbud 3, No, 1. h. 55-56.
} 


\section{Acknowledgments}

We would like to acknowledge the Educational Fund Management. Institution of Indonesia (Scholarship for Excellence for Domestic Indonesian Lecturers). and thanks to the parties who have supported, either directly or indirectly, in making this article.

\section{Reference}

Books

Angraini Titi dkk. (2011) Menata Kembali Pengaturan Pemilukada. Jakarta. Perludem.

Huda Ni'matul. (2015). Hukum Pemerintahan Desa Dalam Konstitusi Indonesia sejak Kemerdekaan sampai Reformasi. Malang. Setara Press.

International Institute for Democracy and Electoral Assistance. (2010), Keadilan Pemilu. Ringkasan Buku Acuan International IDEA. Jakarta. Indonesia Printer.

Mashab Mashuri. (2013). Politik Pemerintahan Desa di Indonesia Cetakan 1. Yogyakarta. Fisip UGM.

Marzuki PM. (2012). Penelitian Hukum. Jakarta. Kencana Prenada Media Group.

Mustofa Syahrul. (2017). Mahkamah Penyelesaian Sengketa Pemilihan Kepala Desa Serentak. Bogor. Guepedia.

Surbakti Ramlan. Dkk. (2011). Penanganan Sengketa Pemilu. Jakarta. Kemitraan Bagi Pembaharuan Tata Pemerintahan.

\section{Journal}

Ahmad, H., Anshari, T., \& Widagdo, S. (2018). Politik Hukum Pengaturan Penyelesaian Perselisihan Hasil Pemilihan Kepala Desa. Mahkamah: Jurnal Kajian Hukum Islam, 3(1), 129-140.

Dewi, S. C., \& Putra, D. N. R. A. PROBLEMATIKA MODEL PENYELESAIN SENGKETA PEMILIHAN KEPALA DESA. Kertha Wicara: Journal Ilmu Hukum, 8(6), 1-18.

Muryati, D. T., \& Heryanti, B. R. (2011). Pengaturan dan Mekanisme Penyelesaian Sengketa Nonlitigasi di Bidang Perdagangan. Jurnal Dinamika Sosbud, 3(1), 4965.

Musdar, M., Tatawu, G., \& Sinapoy, M. S. Analisis Hukum Penyelesaian Sengketa Pemilihan Kepala Desa di Kabupaten Kolaka. Halu Oleo Legal Research, 1(1), 123-141.

Mutiarasari, N. N., \& Herawati, R. Supervision of Bawaslu Pemalang Regency in the 2020 Regional Head Election. LAW REFORM, 16(2), 264-275.

Praptianingsih, S., \& Fauziyah, F. THE DISPUTE RESOLUTION MODEL OF VILLAGE HEAD ELECTION THROUGH NON LITIGATION. Tadulako Law Review, $2(1), 25-37$.

Putra, B. A. (2015). Model Penyelesaian Perselisihan Hasil Pemilihan Kepala Desa. Kumpulan Jurnal Mahasiswa Fakultas Hukum, (1).

Rudiadi, R., \& Herawati, R. (2017). PEMILIHAN KEPALA DESA SERENTAK DALAM PERSPEKTIF OTONOMI DESA (Studi Kasus Pelaksanaan Pemilihan Kepala Desa Serentak Tahun 2016 di Kabupaten Rokan Hilir, Provinsi Riau). LAW REFORM, 13(1), 132-151.

Wance, M. (2019). Faktor Penyebab Konflik Pemilihan Kepala Desa Serentak Di Kabupaten Halmahera Selatan. Journal of Governance and Local Politics, 1(2), 157-174

\section{Laws and Regulations}


Undang-Undang Dasar Negara Republik Indonesia Tahun 1945

Undang-Undang Nomor 6 Tahun 2014 Tentang Desa (Lembaran Negara Republik Indonesia Tahun 2014 Nomor 7, Tambahan Lembaran Negara Republik Indonesia Nomor 5495)

Undang-Undang Nomor 23 Tahun 2014 Tentang Pemerintahan Desa (Lembaran Negara Republik Indonesia Tahun 2014 Nomor 244, Tambahan Lembaran Negara Republik Indonesia Nomor 5587)

Peraturan Pemerintah Nomor 43 Tahun 2014 Tentang Peratura Pelaksanaan UndangUndang Nomor 6 Tahun 2014 Tentang Desa. (Lembaran Negara Republik Indonesia tahun 2014 Nomor 123, Tambahan Lembaran Negara Republik Indonesia Nomor 5539)

Peraturan Menteri Dalam Negeri 112 Tahun 2014 tentang Pemilihan Kepala Desa. (Berita Negara Republik Indonesia Tahun 2014 Nomor 2092)

\section{Website}

https:// sejarawan muda. wordspress.com/2017/07/01 demokrasi asli indonesia dan kedaulatan rakyat Mohammad Hatta/diakses pada hari minggu 16 Maret 2018.

Master Karton Thursday, May 30 2013. http://katonmedia. blogspot.com/2013/05/ pemilihan-kepala desa-dari-jaman.diakses 12 Maret 2019. 